\title{
Extramedullary endobronchial plasmacytoma
}

\author{
Sebastián Fernández-Bussy, ${ }_{1}^{1}$ Gonzalo Labarca, ${ }^{2}$ Erik Folch, ${ }^{3}$ Adnan Majid ${ }^{3}$
}

1 Division of Interventional Pulmonology, Clinica AlemanaUniversidad del Desarrollo, Santiago, Chile

${ }^{2}$ Clinica Alemana-Universidad del Desarrollo, Santiago, Chile ${ }^{3}$ Division of Thoracic Surgery and Interventiona Pulmonology, Beth Israel Deaconess Medical Center Harvard Medical School, Santiago, Chile

\section{Correspondence to}

Dr. Sebastián Fernández-Bussy, sfernandezbussy@alemana.cl

\section{DESCRIPTION}

A 58-year-old man with a history of multiple myeloma was admitted to the hospital with progressive dyspnoea and hypoxemia. Chest examination revealed decreased breath sounds bilaterally. Blood examination revealed anaemia. Chest $\mathrm{x}$-ray and chest CT scan revealed multiple pulmonary nodules, segmental atelectasis and central bronchial narrowing. Flexible bronchoscopy showed nodular lesions with extensive mucosa and submucosal infiltration, which extended from the proximal bronchus intermedius to the right lower lobe bronchus. A large nodular lesion was also noted at the posterior membrane of the proximal left mainstem bronchus (figure 1) and in the rigth bronchus intermedius (figure 2). Biopsies were taken with flexible forceps.

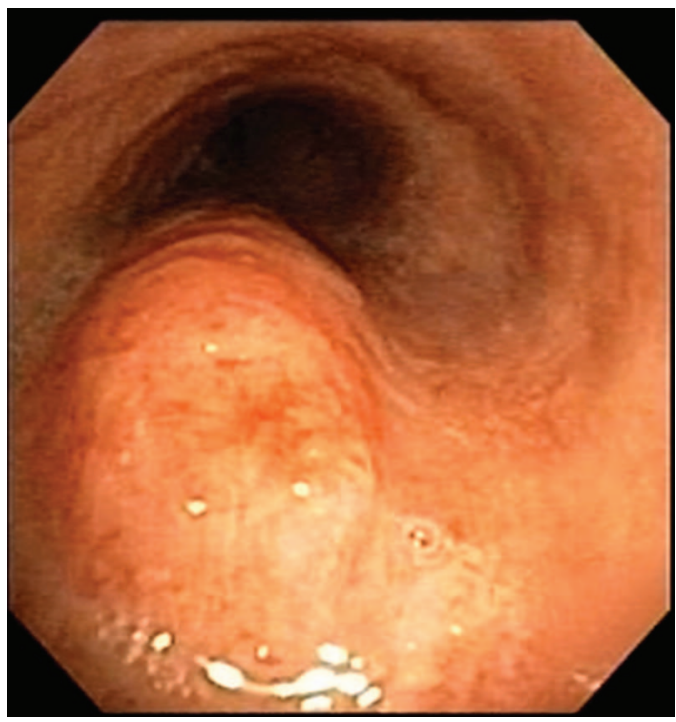

Figure 1 A large nodular lesion was noted at the posterior membrane of the proximal left mainstem bronchus that extends distally with mucosal erythema.
Endobronchial biopsies showed extensive tumour infiltration with plasmocytoid cells, ovoid irregular excentric nuclei, prominent nucleoli, eosinophilic cytoplasm with a paranucleus pale area. High mitosis rate and frequent apoptotic figures were seen (figure 3). Immunohistochemistry was positive for CD-138 and MUM-1. Only $\kappa$-light immunoglobulin chains were noted. This results suggest that the tumor was plasma cell origin with light chain restriction. Extramedullary plasmacytoma (EMP) is a plasma cell neoplasm that arises outside the bone. ${ }^{1}$ EMP is rare and is observed in only 5\% of all plasmacytomas. Endobronchial plasmacytoma is a rare manifestation from EMP. ${ }^{12}$

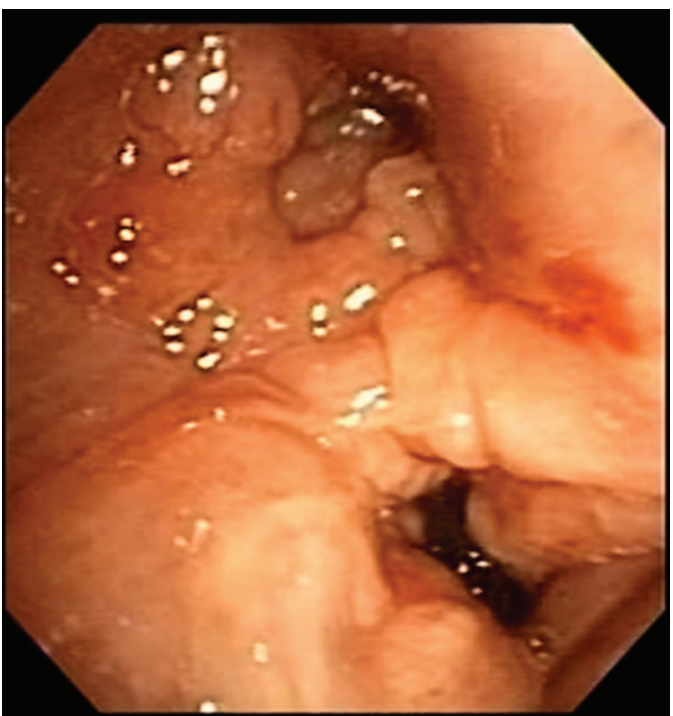

Figure 2 Extensive mucosa and submucosal infiltration at the distal-end of the bronchus intermedius with complete narrowing of the middle lobe and severe narrowing of the right lower lobe.
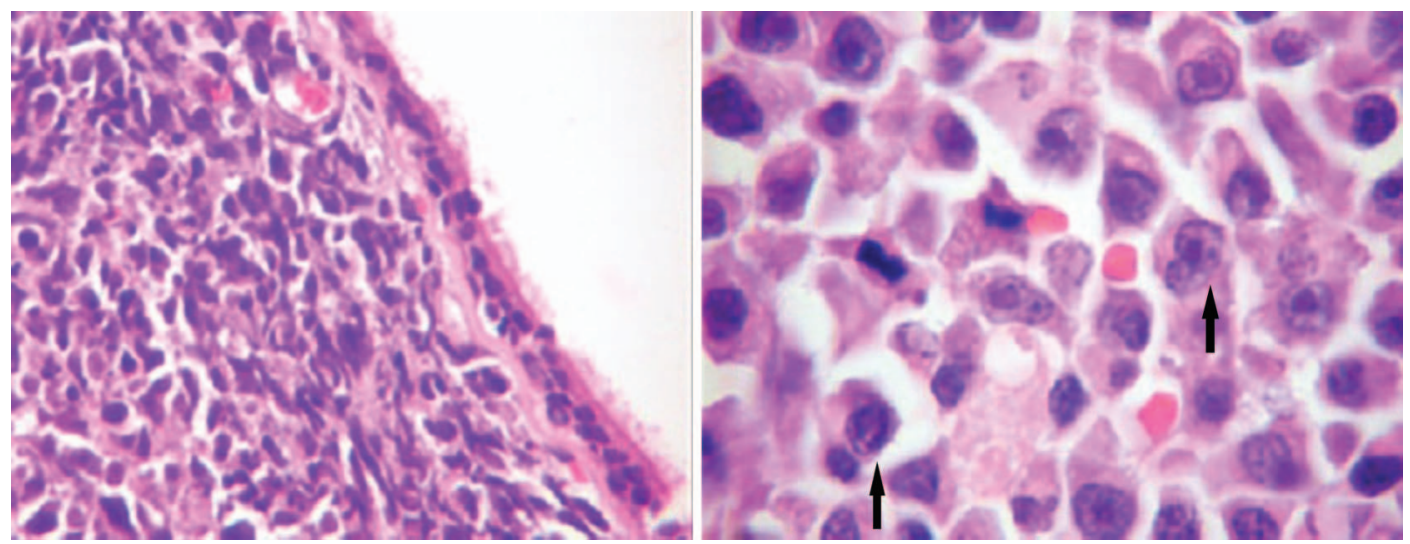

Figure 3 Left: $\times 40$ hematoxylin and Eosin staining of the bronchial partition; presence of a lymphoproliferative infiltration. Right: $\times 100$ hematoxylin and Eosin staining showing atypical plasma cells with a high mitosis rate. 


\section{Learning points}

- Extramedullary plasmacytoma (EMP) is an uncommon condition associated with haematological disease when neoplastic plasma cells arise outside the bone.

- Lower airways compromise is an unusual presentation of EMP, few cases have been reported.

- Histopathological study is required for diagnosis; bronchoscopy is an effective tool to visualise and obtain a biopsy sample.
Competing interests None.

Patient consent Obtained.

\section{REFERENCES}

1 Weber DM. Solitary bone and extramedullary plasmacytoma. Hematology Am Soc Hematol Educ Program 2005;45:373-6.

2 Edelstein $\mathrm{E}$, Gal $\mathrm{AA}$, Mann $\mathrm{KP}$, et al. Primary solitary endobronchial plasmacytoma. Ann Thorac Surg 2004;78:1448-9.

Copyright 2013 BMJ Publishing Group. All rights reserved. For permission to reuse any of this content visit http://group.bmj.com/group/rights-licensing/permissions.

BMJ Case Report Fellows may re-use this article for personal use and teaching without any further permission.

Become a Fellow of BMJ Case Reports today and you can:

- Submit as many cases as you like

- Enjoy fast sympathetic peer review and rapid publication of accepted articles

- Access all the published articles

- Re-use any of the published material for personal use and teaching without further permission

For information on Institutional Fellowships contact consortiasales@bmjgroup.com

Visit casereports.bmj.com for more articles like this and to become a Fellow 